\title{
Influence of exercise on the activity and the distribution between free and bound forms of glycolytic and associated enzymes in tissues of horse mackerel
}

V.I. Lushchak $1, *$, T.V. Bagnyukova ${ }^{1, *}$, J.M. Storey ${ }^{2}$ and K.B. Storey ${ }^{2}$

\author{
${ }^{1}$ Department of Natural Sciences, Precarpathian University, Ivano-Frankivsk, U kraine \\ ${ }^{2}$ Institute of Biochemistry and Department of Biology, Carleton University, Ottawa, \\ O ntario, Canada
}

\section{Correspondence \\ V.I. Lushchak \\ Department of $\mathrm{N}$ atural Sciences \\ Precarpathian University \\ 57 Shevchenko str. \\ Ivano-Frankivsk, 76000 \\ Ukraine \\ E-mail: lushchak@ pu.if.ua \\ ${ }^{*}$ On leave from Karadag $N$ atural Reserve, National Academy of Sciences of U kraine, Kurortne, Feodosia, Crimea, U kraine}

Received April 17, 2000 Accepted M ay 15, 2001

\section{Abstract}

The effects of short-term burst ( $5 \mathrm{~min}$ at $1.8 \mathrm{~m} / \mathrm{s}$ ) swimming and longterm cruiser $(60 \mathrm{~min}$ at $1.2 \mathrm{~m} / \mathrm{s})$ swimming on maximal enzyme activities and enzyme distribution between free and bound states were assessed for nine glycolytic and associated enzymes in tissues of horse mackerel, Trachurus mediterraneus ponticus. The effects of exercise were greatest in white muscle. The activities of phosphofructokinase (PFK), pyruvate kinase (PK), fructose-1,6-bisphosphatase (FBPase), and phosphoglucomutase (PGM) all decreased to 47, 37, 37 and $67 \%$, respectively, during 60-min exercise and all enzymes except phosphoglucoisomerase (PGI) and PGM showed a change in the extent of binding to subcellular particulate fractions during exercise. In red muscle, exercise affected the activities of PGI, FBPase, PFK, and lactate dehydrogenase (LDH) and altered percent binding of only PK and LDH. In liver, exercise increased the PK activity 2.3-fold and reduced PGI 1.7-fold only after $5 \mathrm{~min}$ of exercise but altered the percent binding of seven enzymes. Fewer effects were seen in brain, with changes in the activities of aldolase and PGM and in percent binding of hexokinase, PFK and PK. Changes in enzyme activities and in binding interactions with subcellular particulate matter appear to support the altered demands of tissue energy metabolism during exercise.

\section{Introduction}

Horse mackerel (Trachurus mediterraneus ponticus) are highly active, pelagic fish that can swim at intermediate speed for long periods of time as well as in brief high-speed bursts for shorter periods (1). Intensification of swimming is powered by creatine phosphate hydrolysis and by ATP synthesis via

\section{Key words}

- Trachurus mediterraneus

- Swimming exercise

- Glycolysis

- Subcellular enzyme binding 
AMP and IMP (1-9). In addition, exercise increased both total glycogen phosphorylase activity and the percentage of enzyme in the active, $\underline{a}$ form for an overall 6 -fold increase in the amount of active phosphorylase in trout white muscle (8). The activation of energy metabolism in fish involves several regulatory mechanisms acting in concert; allosteric regulation, protein phosphorylation and enzyme binding to subcellular macromolecules all contribute to the activation of different enzymes (10). The most controversial of these mechanisms is reversible enzyme binding to subcellular macromolecules.

Enzyme binding to cellular macromolecules has been reported extensively. For example, enzymes of glycogen metabolism bind to glycogen particles, AMP-deaminase binds to myosin, and various glycolytic enzymes bind to filamentous actin (11-14). The distribution of enzymes between free and bound forms may, in turn, be modulated by changes in metabolite and ion levels (1517) or by reversible protein phosphorylation (18). The physiological relevance of some interactions is obvious (e.g., glycogen phosphorylase or synthetase binding to glycogen), but the functional significance of glycolytic enzyme association with F-actin has been the subject of debate $(13,17,19)$. These interactions can change enzyme functional properties. For example, bound lactate dehydrogenase (LDH) is not inhibited by high concentrations of pyruvate $(20,21)$, and is more stable to trypsin hydrolysis than the free enzyme (22). Catalytic properties can also be modified by enzyme interaction with structural elements (21-25).

A redistribution of glycolytic enzymes between bound and soluble fractions has been noted in several systems as a response to stimuli that change glycolytic flux (e.g., exercise, anoxia, hypoxia) (26-28), including trout white muscle $(12,29)$. In general, an increase in enzyme binding correlates with an increase in glycolytic flux and vice versa.
But in our recent studies with a teleost fish, the sea scorpion, subjected to hypoxia we found that binding of some enzymes increased whereas binding of other enzymes decreased under the same stress conditions (30). Therefore, to determine whether this was an isolated instance or a common response by fish muscle, we undertook a comparable study with another teleost species.

The present study analyzes the effects of swimming exercise under two regimens, short-term burst exercise and long-term cruiser exercise, on the maximal activities and free versus bound distribution of enzymes in four tissues (brain, liver, and red and white muscle) of the Black Sea teleost fish, the horse mackerel. The results show that activities and distribution of enzymes are modified during exercise and that the effects are dependent on the intensity of swimming.

\section{Material and Methods}

\section{Experimental animals}

Horse mackerel (Trachurus mediterraneus ponticus Aleev) weighing 25-40 g were caught in October 1995 at Karadag Bay, Black Sea (Crimea, Ukraine) and were held in tanks provided with flowing sea water on a native dark/light cycle and temperature of $16 \pm 1^{\circ} \mathrm{C}$. Fish were not fed and were used the next day.

\section{Biochemical reagents and coupling enzymes}

All chemicals were obtained from Boehringer Mannheim (Montreal, PQ, Canada), Sigma Chemical Co. (St. Louis, MO, USA) or Reachim (Russia, USSR).

\section{Fish exercise}

Fish were gently netted from the holding tank and transferred to a specially constructed hydrodynamic tube providing linear laminar 
flow of water and equipped with an electric engine as described earlier (1). Eight fish were used in one experiment which was started about 6-7 am. Initially, water flow was held at low speed $(0.1-0.3 \mathrm{~m} / \mathrm{s})$ for $1 \mathrm{~h}$. After that, four fish were removed as controls and the rest were exercised for $60 \mathrm{~min}$ at a speed of $1.2 \mathrm{~m} / \mathrm{s}$ (cruiser exercise) before sampling. In previous work from our laboratory it was shown that under this regimen fish may swim for several hours (1). Other fish were exposed to the same 1-h low speed swimming but this was then followed by $5 \mathrm{~min}$ at a speed of $1.8 \mathrm{~m} / \mathrm{s}$ (burst exercise); fish in this group were exercised and sampled individually. All fish were killed quickly by trans-spinal dissection and tissue samples were immediately removed and used for the preparation of homogenates; this process took about 2 min. Whole brain and liver, and portions of red and white muscle were used for analysis. White muscle samples were always removed from the same position in the body, just below the first spinal fin.

\section{Preparation of tissue extracts}

Exercised tissues were quickly washed in ice-cold $0.9 \% \mathrm{NaCl}$, blotted on filter paper, weighed and homogenized in a Potter homogenizer with a glass pestle in 10 volumes of homogenization solution containing 0.25 $\mathrm{M}$ sucrose, $10 \mathrm{mM}$ dithiothreitol (DTT), 20 $\mathrm{mM} \mathrm{NaF}, 1 \mathrm{mM}$ EDTA, and $20 \mathrm{mM}$ imidazole- $\mathrm{HCl}, \mathrm{pH} 7.0$, at $20^{\circ} \mathrm{C} ; 0.1 \mathrm{mM}$ phenylmethylsulfonyl fluoride (PMSF, a protease inhibitor) was added immediately before homogenization (30). The homogenate was centrifuged for $20 \mathrm{~min}$ at $45,000 \mathrm{~g}$ at $4{ }^{\circ} \mathrm{C}$ and the supernatant was removed and stored on ice. Enzyme activity in the supernatant represents the free enzyme fraction. The pellet was rehomogenized in 5 volumes (relative to initial tissue weight) of the second homogenization solution with a high salt content to release bound enzymes ( $0.25 \mathrm{M}$ sucrose, 10
mM DTT, $20 \mathrm{mM} \mathrm{NaF}, 1 \mathrm{mM}$ EDTA, 20 $\mathrm{mM}$ imidazole- $\mathrm{HCl}$ and $500 \mathrm{mM} \mathrm{KCl}$ ). After centrifugation, the supernatant was removed and the pellet was extracted a second time and centrifuged and the second supernatant was combined with the first. Enzyme activity in this fraction represents the bound enzyme fraction. Enzyme activities were quantified in both free and bound fractions and the percent binding was calculated. Recovery of total enzyme activity was checked in all cases by comparing the sum of enzyme activities in free and bound fractions with total enzyme activities measured in tissue homogenates. Recovery was close to $100 \%$ in most cases, ranging from 80 to $120 \%$. The maximal enzyme activities (units/g wet weight) shown in the tables are those measured in whole homogenates.

\section{Measurement of enzyme activities}

Maximal activities were assayed at $25^{\circ} \mathrm{C}$ using a KFK-324 spectrophotometer (Lomo, Leningrad, Russia) by monitoring the change in absorbance of NADH or NADPH at 340 $\mathrm{nm}$. All reaction mixtures contained $50 \mathrm{mM}$ imidazole- $\mathrm{HCl}, \mathrm{pH} 7.0$, in a final volume of $1.0 \mathrm{ml}$ including the added extract. Blanks did not contain the most specific substrate (indicated by an asterisk in the assays below). Reactions were started by the addition of the specific substrate but, if no spontaneous change in absorbance was observed, subsequent assays were started by the addition of homogenate. Optimal assay conditions were based on those described earlier (30) and adapted to our experiments. Hexokinase (HK, EC 2.7.1.1): $10 \mathrm{mM}$ glucose (*), $0.2 \mathrm{mM}$ NADP, $2 \mathrm{mM}$ ATP, $5 \mathrm{mM}$ $\mathrm{MgCl}_{2}, 0.5$ unit (U) glucose-6-phosphate dehydrogenase (G6PDH), and $50 \mu 1$ supernatant. Phosphoglucoisomerase (PGI, EC 5.3.1.9): $2.5 \mathrm{mM}$ fructose-6-phosphate $(*)$, $0.2 \mathrm{mMNADP}, 5 \mathrm{mM} \mathrm{MgCl}_{2}, 0.5 \mathrm{U} \mathrm{G6PDH}$, and 5-10 $\mu \mathrm{l}$ supernatant. Phosphofructokinase (PFK, EC 2.7.1.11): 5 mM fructose-6- 
phosphate $(*), 5$ mM ATP, 0.15 mMNADH, $10 \mathrm{mM} \mathrm{MgCl}_{2}, 50 \mathrm{mM} \mathrm{KCl}, 0.5 \mathrm{U}$ aldolase (Ald), $0.5 \mathrm{U}$ triosephosphate isomerase, $2 \mathrm{U}$ glycerol-3-phosphate dehydrogenase, and 30$50 \mu 1$ supernatant. Ald (EC 4.1.2.13): 0.5 mM fructose-1,6-bisphosphate (*), $0.15 \mathrm{mM}$ $\mathrm{NADH}, 0.5 \mathrm{U}$ triosephosphate isomerase, 2 U glycerol-3-phosphate dehydrogenase, and 2-20 $\mu 1$ supernatant. Pyruvate kinase (PK, EC 2.7.1.40): $10 \mathrm{mM}$ phosphoenolpyruvate (*), $2.5 \mathrm{mM}$ ADP, $50 \mathrm{mM} \mathrm{KCl}, 5 \mathrm{mM} \mathrm{MgCl}_{2}$, 0.15 mM NADH, $0.5 \mathrm{U}$ LDH, and 1-10 $\mu 1$

Table 1. Effect of exercise on the activities (units/g wet weight) of glycolytic and associated enzymes in white muscle of horse mackerel.

\begin{tabular}{llcl}
\hline Enzyme & Control & 5-min burst exercise & 60-min cruiser exercise \\
\hline HK & $0.28 \pm 0.09$ & $0.25 \pm 0.06$ & $0.17 \pm 0.02$ \\
PGI & $14.5 \pm 0.4$ & $15.6 \pm 0.7$ & $13.9 \pm 0.2$ \\
PFK & $0.76 \pm 0.03$ & $0.55 \pm 0.08^{\mathrm{a}}$ & $0.36 \pm 0.04^{\mathrm{a}, \mathrm{b}}$ \\
Ald & $52.4 \pm 8.7$ & $54.3 \pm 4.5$ & $70.4 \pm 7.1$ \\
PK & $241 \pm 24$ & $112 \pm 13^{\mathrm{a}}$ & $88.0 \pm 7.7^{\mathrm{a}}$ \\
LDH & $140 \pm 4$ & $131 \pm 17$ & $121 \pm 9$ \\
PGM & $3.01 \pm 0.16$ & $2.41 \pm 0.15$ & $2.01 \pm 0.32^{\mathrm{a}}$ \\
FBPase & $0.57 \pm 0.04$ & $0.43 \pm 0.05^{\mathrm{a}}$ & $0.21 \pm 0.01^{\mathrm{a}, \mathrm{b}}$
\end{tabular}

Data are reported as means \pm SEM of 3-4 determinations in tissue from separate individuals. ap $<0.05$ compared to the corresponding control value and $\mathrm{bP}<0.05 \mathrm{com}$ pared to the 5-min burst exercise group (two-tailed Dunnett test).

$\mathrm{HK}$, hexokinase; PGI, phosphoglucoisomerase; PFK, phosphofructokinase; Ald, aldolase; PK, pyruvate kinase; LDH, lactate dehydrogenase; PGM, phosphoglucomutase; FBPase, fructose-1,6-bisphosphatase.

Table 2. Effect of exercise on the activities (units/g wet weight) of glycolytic and associated enzymes in red muscle of horse mackerel.

\begin{tabular}{lccc}
\hline Enzyme & Control & 5-min burst exercise & 60-min cruiser exercise \\
\hline HK & $0.42 \pm 0.04$ & $0.48 \pm 0.03$ & $0.39 \pm 0.02$ \\
PGI & $9.45 \pm 0.93$ & $6.23 \pm 0.92^{\mathrm{a}}$ & $9.35 \pm 0.36^{\mathrm{b}}$ \\
PFK & $0.17 \pm 0.02$ & $1.93 \pm 0.61^{\mathrm{a}}$ & $0.20 \pm 0.01^{\mathrm{b}}$ \\
Ald & $14.2 \pm 1.2$ & $11.4 \pm 1.9$ & $11.6 \pm 1.6$ \\
PK & $136 \pm 13$ & $122 \pm 4$ & $111 \pm 4$ \\
LDH & $31.7 \pm 3.3$ & $56.8 \pm 5.6^{\mathrm{a}}$ & $36.7 \pm 1.9^{\mathrm{b}}$ \\
PGM & $1.12 \pm 0.04$ & $1.12 \pm 0.07$ & $0.93 \pm 0.05$ \\
FBPase & $0.55 \pm 0.12$ & $0.23 \pm 0.08^{\mathrm{a}}$ & $0.18 \pm 0.01^{\mathrm{a}}$
\end{tabular}

Data are reported as means \pm SEM of 3-4 determinations in tissue from separate individuals. ap $<0.05$ compared to the corresponding control value and $\mathrm{bP}<0.05 \mathrm{com}$ pared to the 5-min burst exercise group (two-tailed Dunnett test).

For abbreviations, see legend to Table 1. supernatant. LDH(EC 1.1.1.27): $1 \mathrm{mM}$ pyruvate $\left(^{*}\right), 0.15 \mathrm{mMNADH}, 1 \mathrm{mMEDTA}$, and 1-50 $\mu 1$ supernatant. G6PDH (EC 1.1.1.49): $2.0 \mathrm{mM}$ glucose-6-phosphate $(*), 5 \mathrm{mM}$ $\mathrm{MgCl}_{2}, 0.2 \mathrm{mM} \mathrm{NADP}$, and 20-50 $\mu 1$ supernatant. Phosphoglucomutase (PGM, EC 2.7.5.1): $15 \mathrm{mM}$ glucose-1-phosphate $(*)$, $0.20 \mathrm{mM}$ NADP, $5.0 \mathrm{mM} \mathrm{MgCl}_{2}, 0.5 \mathrm{U}$ G6PDH, and 20-50 $\mu 1$ supernatant. Fructose-1,6-bisphosphatase (FBPase, EC 3.1.3.11): 0.1 mM fructose-1,6-bisphosphate $\left(^{*}\right), 0.2 \mathrm{mM}$ NADP, $5 \mathrm{mM} \mathrm{MgCl} 2,0.5 \mathrm{U}$ G6PDH, $0.5 \mathrm{U}$ PGI, and 30-50 $\mu$ l supernatant. One unit of enzyme activity is defined as the amount of enzyme that utilizes $1 \mu \mathrm{mol}$ of substrate per $1 \mathrm{~min}$ at $25^{\circ} \mathrm{C}$. All values are expressed as means $\pm \mathrm{SEM}$. Differences between means were determined by analysis of variance followed by the two-tailed Dunnett test. For technical reasons, the number of animals was limited (3-4 per set) but, even so, in many cases we obtained statistically significant differences between experimental groups.

\section{Results}

The effect of exercise under both regimens on the activities of glycolytic and associated enzymes is shown in Tables 1-4. In white muscle, exercise resulted in a significant decrease in the activities of several enzymes (Table 1). Activities of PFK, PK and FBPase decreased under both exercise regimens, whereas PGM was reduced by $33 \%$ only after long-term cruiser swimming. After 5-min burst exercise, PFK, PK and FBPase activities were reduced to 72,46 , and $75 \%$ of their corresponding control values, but 60 min of sustained exercise had an even greater effect, lowering activities to 47 , 36 and $37 \%$ of the controls, respectively. The activities of four enzymes were affected by exercise in red muscle (Table 2). The activities of PGI and FBPase decreased significantly after 5 -min burst exercise falling to 66 and $42 \%$, respectively, of their control 
values. FBPase activity was also reduced after 60 -min cruiser swimming to $33 \%$ of the control value. By contrast, PFK activity rose by 11 -fold and LDH by 1.8 -fold after 5 -min burst exercise. However, neither enzyme was affected by sustained 60 -min swimming. In liver, stimulation of swimming affected only PGI and PK during 5-min burst swimming (Table 3). PGI activity fell to $59 \%$ of the control value whereas PK activity rose by 2.3-fold. No enzymes were affected during sustained cruiser swimming. In brain, Ald activity increased by $62 \%$ during both forms of exercise, whereas PGM activity was sharply reduced to $32 \%$ of control after 60 min sustained exercise and was undetectable in the tissue from fish submitted to 5-min burst exercise (Table 4). FBPase was also undetectable in brain of exercised fish.

Figures 1-4 show the distribution of enzymes between free and bound forms in horse mackerel tissues. In white muscle, swimming exercise led to the redistribution of six of eight enzymes, but did not affect PGI or PGM (Figure 1). Short-term burst swimming significantly reduced the percentage of bound PFK, Ald and FBPase and released all $\mathrm{HK}$ into the free fraction. In contrast, bound PK rose from about 15 to $54 \%$ of the total and the percentage of bound LDH also doubled. Sustained cruiser swimming had different effects on the distribution of enzymes in white muscle. Although PFK and PK responded similarly to both forms of exercise, the effect on FBPase was much more pronounced with no bound FBPase found in white muscle during this type of swimming. HK, Ald and LDH were unaffected during cruiser swimming.

Red muscle showed fewer changes in the proportions of bound enzymes during swimming exercise. The only effect of burst exercise on this tissue was that bound $\mathrm{LDH}$ dropped by one-half. By contrast, sustained cruiser exercise affected the bound proportion of four enzymes - PFK, PK, LDH and PGM. Bound PGM activity was not found at
Table 3. Effect of exercise on the activity (units/g wet weight) of glycolytic and associated enzymes in liver of horse mackerel.

\begin{tabular}{lccc}
\hline Enzyme & Control & 5-min burst exercise & 60-min cruiser exercise \\
\hline HK & $0.58 \pm 0.07$ & $0.40 \pm 0.02$ & $0.65 \pm 0.15$ \\
PGI & $10.8 \pm 1.8$ & $6.4 \pm 0.6^{\mathrm{a}}$ & $8.1 \pm 0.2$ \\
PFK & $0.37 \pm 0.32$ & $0.32 \pm 0.02$ & $0.38 \pm 0.09$ \\
Ald & $2.65 \pm 0.22$ & $2.46 \pm 0.15$ & $2.34 \pm 0.28$ \\
PK & $6.9 \pm 0.4$ & $16.0 \pm 1.7 \mathrm{a}$ & $8.0 \pm 0.6^{\mathrm{b}}$ \\
LDH & $1.57 \pm 0.37$ & $1.64 \pm 0.18$ & $1.26 \pm 0.08$ \\
PGM & $3.12 \pm 0.28$ & $2.87 \pm 0.37$ & $2.31 \pm 0.28$ \\
G6PDH & $5.63 \pm 0.60$ & $4.45 \pm 0.64$ & $3.92 \pm 0.04$ \\
FBPase & $2.88 \pm 0.26$ & $2.43 \pm 0.27$ & $2.76 \pm 0.19$ \\
\hline
\end{tabular}

Data are reported as means \pm SEM of 3-4 determinations in tissue from separate individuals. ap $<0.05$ compared to the corresponding control value and ${ }^{\mathrm{b} P}<0.05 \mathrm{com}$ pared to the 5-min burst exercise group (two-tailed Dunnett test).

G6PDH, glucose-6-phosphate dehydrogenase. For other abbreviations, see legend to Table 1.

Table 4. Effect of exercise on the activities (units/g wet weight) of glycolytic and associated enzymes in brain of horse mackerel.

\begin{tabular}{llcc}
\hline Enzyme & Control & 5-min burst exercise & 60-min cruiser exercise \\
\hline HK & $0.21 \pm 0.04$ & $0.21 \pm 0.01$ & $0.18 \pm 0.01$ \\
PGI & $3.72 \pm 0.11$ & $3.97 \pm 0.11$ & $3.72 \pm 0.11$ \\
PFK & $0.18 \pm 0.03$ & $0.24 \pm 0.03$ & $0.25 \pm 0.01$ \\
Ald & $1.66 \pm 0.11$ & $2.69 \pm 0.18^{a}$ & $2.69 \pm 0.12^{a}$ \\
PK & $36.5 \pm 1.8$ & $34.5 \pm 1.7$ & $33.3 \pm 1.2$ \\
LDH & $9.20 \pm 0.43$ & $7.49 \pm 0.36$ & $8.24 \pm 0.83$ \\
PGM & $0.22 \pm 0.06$ & 0 & $0.07 \pm 0.03^{a}$ \\
G6PDH & $0.07 \pm 0.01$ & 0 & $0.08 \pm 0.02$ \\
FBPase & $0.05 \pm 0.02$ & 0 & 0 \\
\hline
\end{tabular}

Data are reported as means \pm SEM of 3-4 determinations in tissue from separate individuals. ap $<0.05$ compared to the corresponding control value (two-tailed Dunnett test).

G6PDH, glucose-6-phosphate dehydrogenase. For other abbreviations, see legend to Table 1.

Figure 1. Effect of exercise on the distribution of glycolytic and associated enzymes between free and bound fractions in white muscle of horse mackerel. Control (white bars), 5-min burst swimming (grey bars) and 60min cruiser swimming (black bars). Data are reported as means \pm SEM $(\mathrm{N}=3-4$ individual fishes). aP $<0.05$ compared to the corresponding control value and bP $<0.05$ compared to the 5 -min burst exercise group (two-tailed

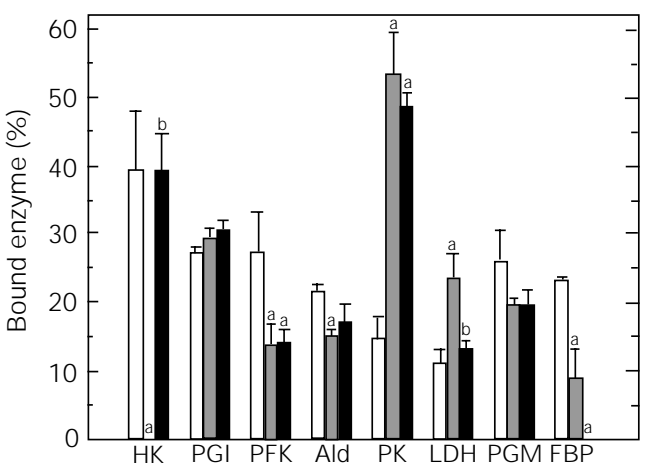

Dunnett test). HK, hexokinase; PGI, phosphoglucoisomerase; PFK, phosphofructokinase; Ald, aldolase; PK, pyruvate kinase; LDH, lactate dehydrogenase; PGM, phosphoglucomutase; FBP, fructose-1,6-bisphosphatase. 
Figure 2. Effect of exercise on the distribution of enzymes bein red muscle of horse mackerel. Other information as in the legtween free and bound fractions end to Figure 1
Figure 3. Effect of exercise on the distribution of enzymes between free and bound fractions in liver of horse mackerel. G6PDH, glucose-6-phosphate dehydrogenase. Other information as in the legend to Figure 1. all, bound PK activity fell compared to control and bound LDH and PFK rose compared to burst exercise in red muscle (Figure 2).

In liver, both exercise regimens led to changes in percent binding of several enzymes but did not affect PFK or Ald distribution (Figure 3). After 5-min burst swimming the percentages of bound HK, PK, FBPase and G6PDH all increased significantly, whereas bound PGI decreased. The increase in bound G6PDH was particularly large, rising from only about $1 \%$ bound in controls to
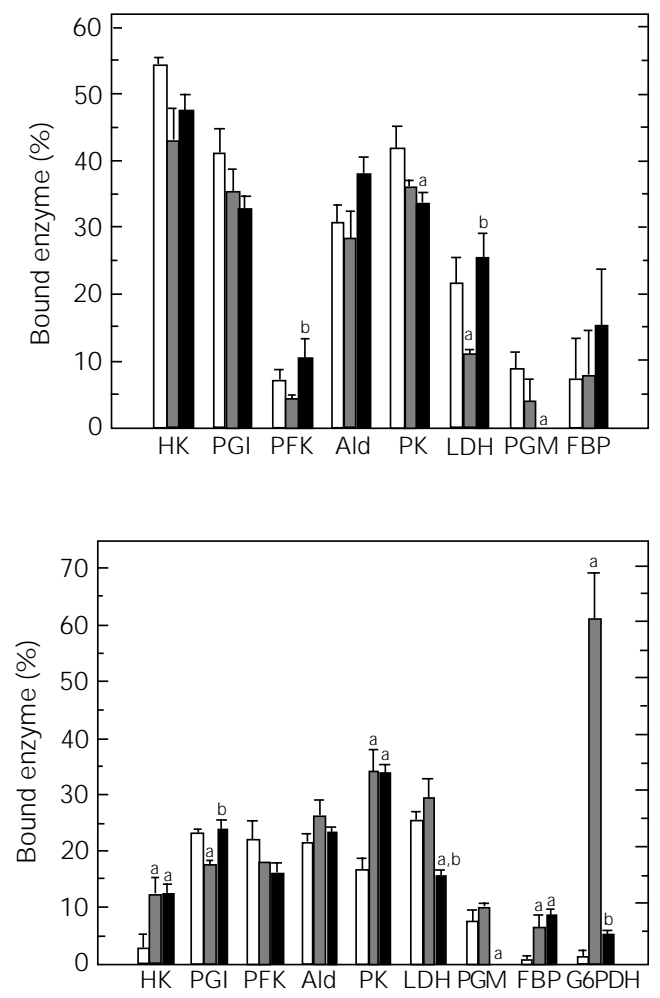

Figure 4. Effect of exercise on the distribution of enzymes between free and bound fractions in brain of horse mackerel. Other information as in the legend to Figure 1.

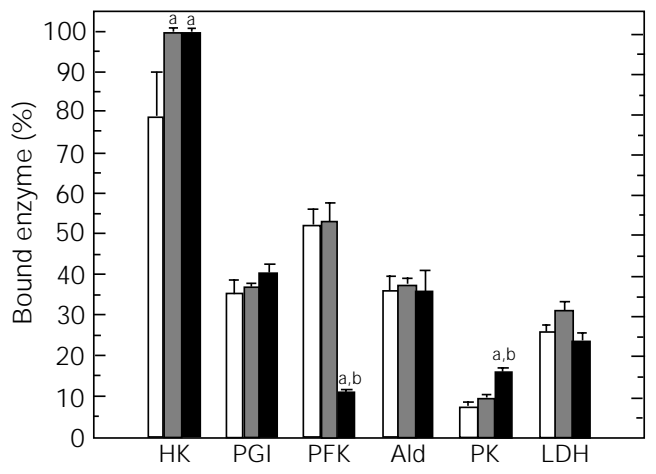

about $61 \%$ after burst exercise. Sustained exercise had the same effects as burst exercise on liver HK, PK and FBPase. However, the percentage of bound PGI and G6PDH did not change during sustained swimming. The proportion of bound LDH was reduced during cruiser swimming in liver compared to both the control and burst exercise situation and, in addition, no bound PGM was found in liver after sustained exercise.

In brain both exercise regimens increased the percentage of bound HK but PGI, Ald and $\mathrm{LDH}$ were unaffected by either form of exercise (Figure 4). PFK binding was not affected during burst exercise, but percent binding fell from about $53 \%$ in control to $11 \%$ after sustained 60 -min swimming. In contrast, the percentage of bound $\mathrm{PK}$ in brain increased from about 8 to $16 \%$ during sustained swimming.

\section{Discussion}

The effect of exercise on intermediary metabolism and energetics of organisms has been well studied (31), including numerous studies of metabolic responses to exercise by fish species $(4,5,8)$. Two areas of exercise metabolism in fish that are still not fully resolved, however, are the effects of exercise on enzyme activities and on the distribution of enzymes between free and bound states. Therefore, in this study we focused on these two phenomena, monitoring the effects of burst high-speed swimming $(5 \mathrm{~min}$ at $1.8 \mathrm{~m} / \mathrm{s}$ ) and of sustained moderate-speed swimming (60 $\mathrm{min}$ at $1.2 \mathrm{~m} / \mathrm{s}$ ) on the maximal activities of enzymes in four organs and on the subcellular distribution of enzymes between free and bound states. Short-term burst exercise is typically powered by white muscle in fish, whereas long-term cruiser exercise is primarily a function of red muscle. Previous work from our Karadag laboratory has analyzed the different modes of swimming and their effects on metabolite levels in horse mackerel tissues. These fish can swim 
for $7-10 \mathrm{~h}$ at a speed of $1.2 \mathrm{~m} / \mathrm{s}(1)$. After $1 \mathrm{~h}$ of swimming at this speed the levels of phosphocreatine were reduced by about $50 \%$ in white muscle and ATP and AMP fell by about $10-20 \%$, whereas ADP and inorganic phosphate levels were increased about $40 \%$. The effects of exercise on the carbohydrate content of horse mackerel tissues were also studied. Glycogen concentration decreased and lactic acid concentration increased during the first 10-30 min of cruiser swimming in white muscle. But even though glycogen had fallen further after $60 \mathrm{~min}$ of exercise, lactate concentration was reduced well below the initial level, suggesting a possible lactate export from the muscle during sustained swimming. Red muscle responded to exercise similarly, although the rates of change in metabolite levels were different.

The results of the present study show that exercise also modifies the activities of enzymes of intermediary metabolism in horse mackerel tissues. The enzymes chosen for study were several glycolytic enzymes as well as the gluconeogenic enzyme FBPase, and G6PDH, the first enzyme of the hexose monophosphate shunt. With the exception of HK, all enzymes showed some exerciserelated change in maximal activity in at least one of the four tissues tested. Both burst and cruiser exercise resulted in reduced activities of PFK, PK and FBPase in white muscle but a relatively constant PFK:FBPase ratio was maintained, suggesting that exercise did not change the relative rates of glycolytic versus gluconeogenic flux in the muscle. The mechanism(s) regulating the coordinated decrease in the maximal activities of PFK, PK and FBPase remain(s) to be determined but notably these three enzymes are typically subject to multiple regulatory controls by a variety of factors. One of these is reversible phosphorylation via protein kinases and phosphatases, which is not a mechanism known to control any of the other five enzymes. Hence, it would be interesting to determine whether exercise stimulated changes in the phosphorylation state of these enzymes.

Exercise-induced changes in the activities of enzymes in red muscle were quite different except that, as in white muscle, the activity of FBPase decreased in exercised muscle. In this case, however, PFK activity did not decrease during exercise (indeed, it rose substantially during burst exercise) so that the net consequence would be a decrease in the potential for gluconeogenic flux during exercise. Indeed, the PFK:FBPase ratio rose from a control value of 0.31 to values during burst and cruiser exercise of 8.39 and 1.11 , respectively, showing that glycolysis is clearly favored during exercise. However, the very large increase in PFK activity during burst work is surprising, since it occurred within $5 \mathrm{~min}$. Hence, this cannot be synthesis of new enzyme, but must represent a change of the existing enzyme either due to effects of very powerful allosteric effectors (whose influence is still felt when the homogenate is diluted about 20 -fold in the assay mixture) or to a stable change of enzyme properties such as those induced by reversible phosphorylation, polymerization or alteration of bound/free status, all known mechanisms of PFK control (32). However, the results illustrated in Figure 2 indicate that a change in the relative amounts of bound versus free PFK could not account for the change in enzyme activity.

Small changes in the activities of glycolytic enzymes in liver and especially in brain suggest that metabolism is not perturbed very much during exercise in these tissues. Burst work typically activates glycogenolysis in vertebrate liver to increase the supply of glucose to the working muscle. This effect is typically accomplished via activation of glycogen phosphorylase coupled with inhibitory control on PFK that facilitates the diversion of hexose phosphates into glucose output. Interestingly, in mackerel liver, a decrease in PGI activity during burst exercise might also suggest that some additional control may be applied at this enzyme locus 
which converts glucose-6-phosphate into fructose-6-phosphate for use by PFK.

Reversible enzyme binding to subcellular structures and other macromolecules is well known but its importance in the control of enzymes and pathways still remains controversial. Previous studies from our laboratories found that the distribution of enzymes of carbohydrate metabolism between free and bound fractions may be modified by exercise in trout $(12,29)$, anoxia in goldfish (28), and hypoxia in sea scorpion (30). However, whereas in the two first species an activation of glycolysis led to an increase or no change in enzyme binding, in sea scorpion tissues the situation was more complicated. With increased glycolytic rate, the bound portion increased in some enzymes, decreased in some and did not change in others (30).

Exercise significantly changed the distribution of various enzymes between free and particle-bound states in horse mackerel tissues. In white muscle, for example, the disappearance of the bound form of HK during burst work and of FBPase after 60-min exercise could significantly change the function of these enzymes. The bound portion of PFK in white muscle also decreased by about one-half in both exercised groups. Detailed studies have suggested that PFK binding may be one of the few interactions between glycolytic enzymes and subcellular structures that have real significance in vivo. This is because PFK binding holds up under physiological conditions of ions and metabolites, whereas interactions between various other glycolytic enzymes and F-actin (believed to be a chief binding site for glycolytic enzymes) frequently disappear at physiological ionic strength (17). However, the present results (reduced PFK binding in exercised muscle) are contrary to results for trout where PFK binding increased during exercise (12, 29). The reason for this contradiction is not apparent from the current data but might be related to differences in the dependence of white muscle from different species on phosphagen versus anaerobic glycolysis for the support of muscle work. PK and LDH responded in opposite ways to PFK during exercise, the percent binding of both enzymes rising during burst exercise and bound PK also rising during cruiser exercise. This may serve to localize these two terminal enzymes of glycolysis at positions that could facilitate sustained anaerobic glycolysis including ATP production by PK and the reoxidation of NADH by LDH.

Contrary to white muscle, red muscle showed very few changes in enzyme distribution during exercise. This type of muscle is used primarily in sustained cruiser exercise but enzyme binding changes during cruiser swimming consisted of only a small decrease in percent PK binding and a complete loss of PGM binding. Burst swimming only changed LDH binding in this muscle. This may not be surprising as long-term cruiser swimming powered by red muscle may be primarily fueled by the oxidation of lipids and hence only small changes in glycolytic rate may occur during this type of exercise.

In liver, several enzymes showed increased percent binding during exercise. One of the most interesting effects may be the increase in HK binding, which was also found in brain. These two findings may be discussed from the point of view of coordination of glycolysis with Krebs cycle operation. It is well known that $\mathrm{HK}$ interacts with porin, a protein in the mitochondrial membrane $(33,34)$. ATP synthesis within the mitochondria provides the ATP for the HK reaction and, at the same time, products of the HK reaction, glucose-6-phosphate and ADP, are processed by glycolysis and mitochondria in the near-mitochondrial space. Unfortunately, there is no comparable information on binding sites for other glycolytic enzymes in liver and brain but the exerciseinduced increase in PK binding might also serve to localize the production of pyruvate, 
a substrate for aerobic oxidation, in a position that better facilitates pyruvate uptake by mitochondria.

There is no doubt that reversible binding of glycolytic and other enzymes to cellular structures can play a role in the precise regulation of metabolism. Unfortunately, to date, the mechanisms involved in this regulation are not well understood (14) and redistribution of different enzymes in different directions, as seen in the present study or in our previous work with sea scorpions (30), makes the picture even more complicated. Such redistribution indicates that this mechanism may be involved in the regulation of glycolysis in its organs, providing space-time compartmentation of the pathway to serve different metabolic needs. The specific enzymes affected in different tissues could result in tissue-specific changes in flux through different pathways in a manner that serves the metabolic needs of each organ.

\section{Acknowledgments}

The authors thank N. Glibina for technical assistance.

\section{References}

1. Shulman GE (Editor) (1978). Elements of Physiology and Biochemistry of General and Active Metabolism in Fishes. Naukova Dumka, Kyiv.

2. Rahim ZHA, Lutaya $G \&$ Griffiths J R (1979). Activation of AMP aminohydrolase during skeletal-muscle contraction. Biochemical J ournal, 184: 173-176.

3. Wokoma A \& J ohnston IA (1983). Anaerobic metabolism during activity in rainbow trout (Salmo gairdneri). Experientia, 39: 1366-1367.

4. Parkhouse WS, Dobson GP, Belcastro AN $\&$ Hochachka PW (1987). The role of intermediary metabolism in the maintenance of proton and charge balance during exercise. Molecular and Cellular Biochemistry, 77: 37-47.

5. Parkhouse WS, Dobson GP \& Hochachka PW (1988). Control of glycogenolysis in rainbow trout muscle during exercise. Canadian J ournal of Zoology, 66: 345-351.

6. Mommsen TP \& Hochachka PW (1988). The purine nucleotide cycle as two temporally separated metabolic units: a study on trout muscle. Metabolism, 37: 552558.

7. Van den Thillart $G$, Van Waarde A, Muller HJ , Erkelens C, Addink A \& Lugtenburg J (1989). Fish muscle energy metabolism measured by in vivo ${ }^{31}$ P-NMR during anoxia and recovery. American J ournal of Physiology, 256: R922-R929.

8. Storey KB (1991). Metabolic consequences of exercise in organs of rainbow trout. J ournal of Experimental Zoology, 260: 157-164.

9. Schulte PM, Moyes CD \& Hochachka PW
(1992). Integrating metabolic pathways in post-exercise recovery of white muscle. J oumal of Experimental Biology, 166: 181195.

10. Lushchak VI (1995). Role of phosphorylation and redistribution of glycolytic enzymes in adaptation of hydrobiontes to enviromental conditions. Hydrobiological J ournal, 31: 18-29.

11. Masters CJ , Reid S \& Don M (1987). Glycolysis - new concepts in an old pathway. Molecular and Cellular Biochemistry, 76: 3-14.

12. Brooks SPJ \& Storey KB (1988). Subcellular enzyme binding in glycolytic control: in vivo studies with fish muscle. American J ournal of Physiology, 255: R289-R294.

13. Lushchak VI (1996). AMP-deaminase: functions, molecular properties and localization in the cell. Biochemistry (Moscow), 61: 195-211.

14. Lushchak VI (1996). Participation of supramolecular complex formation in the regulation of glycolytic enzymes. Ukrainian Biochemical J ournal, 68: 20-28.

15. Hsu SC \& Molday RS (1990). Glyceraldehyde-3-phosphate dehydrogenase is a major protein associated with the plasma membrane of retinal photoreceptor outer segments. J ournal of Biological Chemistry, 265: 13308-13313.

16. Lushchak VI (1991). Properties of membrane-bound lactate dehydrogenase from white skate muscle. Biokhimiia, 56: 21732180.

17. Brooks SPJ \& Storey KB (1993). Control of glycolytic enzyme binding: effect of changing enzyme substrate concentra- tions on in vivo enzyme distribution. Molecular and Cellular Biochemistry, 122: 17.

18. Luther MA \& Lee JC (1986). The role of phosphorylation in the interaction of rabbit muscle phosphofructokinase with Factin. J ournal of Biological Chemistry, 261: 1753-1759.

19. Kurganov BI (1986). The role of multienzyme complexes in integration of cellular metabolism. J ournal of Theoretical Biology, 119: 445-455.

20. Ehmann J D \& Hultin HO (1973). Substrate inhibition of soluble and bound lactate dehydrogenase (isoenzyme 5). Archives of Biochemistry and Biophysics, 154: 471475.

21. Lushchak VI (1992). Lactate dehydrogenase interaction with the structural cell components: the possible physiological significance. Biokhimiia, 57: 1142-1154.

22. Lushchak VI (1992). Free and membranebound lactate dehydrogenase from white driving muscles of skate. Biochemistry International, 26: 905-912.

23. Liou R-S \& Anderson S (1980). Activation of rabbit muscle phosphofructokinase by F-actin and reconstituted thin filaments. Biochemistry, 19: 2684-2688.

24. Kuo H-J , Malencik DA, Liou RS \& Anderson SR (1986). Factors affecting the activation of rabbit muscle phosphofructokinase by actin. Biochemistry, 25: 12781286.

25. Lushchak VI (1993). Free and bound pyruvate kinase from fish brain: properties and redistribution after hypoxia. Biochemistry and Molecular Biology International, 29: 
1103-1109.

26. Clarke FM, Shaw FD \& M orton DJ (1980). Effect of electrical stimulation post mortem of bovine muscle on the binding of glycolytic enzymes. Functional and structural implications. Biochemical J ournal, 186: 105-109.

27. Brooks SPJ \& Storey KB (1991). Studies on the regulation of enzyme binding during anoxia in isolated tissues of Busycon canaliculatum. J ournal of Experimental Biology, 156: 467-481.

28. Duncan J A \& Storey KB (1991). Role of enzyme binding in muscle metabolism of the goldfish. Canadian J ournal of Zoology, 69: 1571-1576.

29. Lushchak VI \& Storey KB (1994). Effect of exercise on the distribution of enzymes in trout white muscle and kinetic properties of AMP-deaminase from free and bound fractions. Fish Physiology and Biochemistry, 13: 226-239.

30. Lushchak VI, Bahnjukova TV \& Storey KB (1998). Effect of hypoxia on the activity and binding of glycolytic and associated enzymes in sea scorpion tissues. Brazilian J ournal of Medical and Biological Research, 31: 1059-1067.

31. Booth FW \& Thompson DB (1991). Molecular and cellular adaptation of muscle in response to exercise: perspectives of various models. Physiological Reviews, 71: 541-585.

32. Storey KB \& Brooks SPJ (1995). Is glyco-
Iytic rate controlled by the reversible binding of enzymes to subcellular structures? In: Hochachka PW \& Mommsen TP (Editors), Biochemistry and M olecular Biology of Fishes. Vol. 4. Elsevier, Amsterdam, 291-307.

33. Depinto V, Aljamal J A \& Palmieri F (1993). Hexokinase-binding protein. Location of the dicyclohexylcarbodiimide-reactive glutamate residue in the bovine heart mitochondrial porin. J ournal of Biological Chemistry, 268: 12977-12982.

34. Hassinen IE \& Vuokila PT (1993). Hexokinase-binding protein. Reaction of dicyclohexylcarbodiimide with mitochondrial proteins. Biochimica et Biophysica Acta, 1144: 107-124 